\title{
Environmental Communication in Kaimana Regency (Descriptive Study on Conservation International(CI) Environmental Communication Activity in the Water Conservation Area of Kaimana Regency)
}

\author{
Heru Ryanto Budiana ${ }^{1}$, Priyo Subekti ${ }^{2,}$ and Dadang Sugiana ${ }^{3}$ \\ Faculty of Communication Science, Universitas Padjadjaran, Indonesia ${ }^{1-3}$ \\ \{priyo.subekti@unpad.ac.id $\left.{ }^{2}\right\}$
}

\begin{abstract}
Environmental communication is about the relationship between humans with nature and the surrounding environment. The appreciation for nature and environment will have an impact on the environment that give benefits to human welfare. On the other hand, if human treats nature arbitrarily, the environment can be a threat to human life. This is what Conservation International (CI) does in supporting Kaimana as a Regional Area of Water Conservation. This study aims to provide an overview of environmental communication activities by CI in Kaimana waters conservation area. This research uses a descriptive method with qualitative data obtained through observation and interview. Informants in this research are the leaders and staff of CI Kaimana The results showed that the environmental communication activities conducted by $\mathrm{CI}$ based on custom conservation, in an effort to educate, socialize and involve Kaimana society participation. Environmental communication through customary approaches, such as sinara. Through mass media, online media such as: website, instagram or youtube. Face-to-face communication, direct discussion with the society and visits to schools conducted by CI with all its limitations, especially in implementing events related to conservation activities.
\end{abstract}

Keywords: Conservation International, Environmental communication, Kaimana

\section{Introduction}

Kaimana Regency is an autonomous regency located in the province of West Papua, which is endowed with abundant natural resources. Kaimana belongs to one of the Regional Marine Protected Areas proclaimed by the Indonesian government. In addition, this area is also part of the World Coral Triangle, a world coral triangle region which becomes the center of diversity of corals and marine in the world.

Wealth of Kaimana waters became one of the considerations of the issuance of Regional Regulation Number 11 of 2014 on Regional Water Conservation Area (KKPD) Kaimana Regency. Other considerations mentioned that the waters, coastal, sea and small islands of Kaimana Regency have high biodiversity, it must be protected and managed and utilized responsibly based on the principle of sustainable development and the consideration that based 
on the mandate of Law Number 31 Year 2004 regarding fisheries as already amended by Law Number 45 Year 2009, in order to manage water resources, coastal, marine and small islands, ecosystem conservation, fish species conservation and fish genetic conservation in coastal and marine areas of Kaimana Regency are required [1]. Issues about the environment have been scrutinized by experts [2]-[4].

Based on the regulation, it is also explained that the location of KKPD Kaimana Regency is 508,324 Ha with four areas covering the Management Areas of Buruway, Arguni, Kaimana, Etna, and Yamor. Management and determination of coastal and marine areas in Kaiamana Regency into KKPD aims to form a protected marine and coastal areas and can be managed on an ongoing basis with guided by the principle of environmental conservation, either by the society itself or others who invest in fisheries and tourism.

Conservation of natural resources in the Kamus Besar Bahasa Indonesia (KBBI), defined as the management of natural resources (biological) with the wise use and guarantee the continuity of the inventory while maintaining and improving the quality value and diversity. While referring to Regional Regulation Number 11 Year 2014 on KKPD Kaimana Regency, said that conservation is an effort to protect the ecosystem life support, germplasm preservation and usage of biodiversity based on the principles of sustainability. Based on the understanding of the conservation, it can be said that conservation is an effort to conserve, protect and usage of the environment for a long period and sustainable [4]-[6].

Awareness about the importance of protecting the environment is important to be communicated continuously by all stakeholders, whether government, public, private, NGOs or other organizations that concerned with the environment. One of the institutions that committed to supporting conservation activities in Kaimana Regency is Conservation International (CI).

\section{Result and discussions}

Based on the documentation study, the determination of marine protected area or Kawasan Konservasi Laut Daerah $(K K L D)$, Kaimana is inseparable from the results of research conducted by Conservation International (CI) in 2007, it is known that Kaimana has beauty and natural wealth, especially unique marine ecosystem with endemic species, for groupers, snapper and a number of fish that have important economic value for capture fisheries, as well as other potentials such as mangrove forests, sea turtles and much more incredible marine potential in Kaimana.

Kaimana Regency as an autonomous district located in West Papua province, which is endowed with abundant natural resources. Kaimana belongs to one of the Regional Marine Protected Areas proclaimed by the Indonesian government. Furthermore, this area is also part of the World Coral Triangle is a world coral triangle region which is the center of diversity of corals and marine life in the world. The research report compiled by Mark G. Allend in 2007, entitled "An Assessment of Coral Reef Fin Fish Resources on the Fakfak Kaimana Coast of Irian Jaya Barat, Indonesia", explains that Kaimana is a Bryde's whale track (an important species because information about this species has not been widely studied), turtle habitat (Green and Scales), 4 species of dolphins and dugong. Kaimana also has 471 species of corals (with an additional 14 to 16 species of possibly new but still in research) and 1000 species of reef fish (2 endemic Kaimana species and 6 endemic species of Papua Bird's Head Seawick). Based on the results of this study, the main locations that have high ecological values and need to be conserved in Kaimana are the districts of Buruway ( $\mathrm{Tj}$ Kumawa, Nusa Ulan, Venu Island) and Triton Bay. The above-mentioned sea potential is supported by a complete coastal 
ecosystem in the Triton and Bicari areas. Mangrove, seagrass and coral reef ecosystems are scattered in both areas and support fisheries sustainability in Kaimana. Results of research on biomass produce the highest number of 228 tons of fish in each square kilometer of the Kaimana sea region[1].

Kaimana has a strategic position in the southern part of Papua Province and facing directly with Arafuru Sea is very beneficial from fishery and marine sector, especially capture fishery. The conservation paradigm established by the Kaimana government in its territory is an effort to maintain environmental quality and ecosystem balance. Utilization of resources owned for the life of Kaimana society while maintaining its sustainability and sustainability and paying attention to local Kaimana wisdom.

The role of environmental communication is crucial in supporting sustainable environmental [7], [8], [9], conservation in the watershed area of Kaimana since environmental communication is essentially protecting the richness of natural resources with its diversity and promoting its sustainability. The approach is holistic, which not only considers the environment solely as a resource provider that needs to be protected but also takes into account the socio-cultural conditions of the local society.

Environmental communication for sustainability in Kaimana is not only through the Local Government, but also by one of the institutions committed to supporting conservation activities in Kaimana Regency, Conservation International (CI). CI as one of the institutions that from the beginning encourage the establishment of Kaimana as a conservation area has been present since KKLD Kaimana declared in 2008 until today.

Based on interviews conducted, CI Indonesia is headquartered in Jakarta, while for maritime affairs CI has representative offices in Bali, Raja Ampat, and Kaimana, and has a joint secretariat office in Manokwari. CI in Kaimana in conducting its environmental communication activities carried out with two strategies namely sustainable tourism and sustainable fisheries while maintaining natural resources and customs in Kaimana. A social approach to indigenous peoples related to environmental conservation benefit is done as an entrance to socialize and conduct conservation activity.

A social approach to Kaimana society, which has its own characteristic, is very important to avoid rejection or social conflict with local people. Rejection of conservation efforts is not uncommon, because it is not socialized benefits and conservation goals are done. This is in line with the narrative[10], that generally the problems that arise related to conservation, among others: 1) Communities around conservation are generally still less involved in joint area management, sometimes even considered enemies; 2) The pattern of incentives developed is less clear in direction and purpose. The government only hopes that society can help maintain the area without any clear agreement. If there is a problem related to the area, the society feels no responsibility for the problems faced.

Rejection incident was experienced by the CI typed Venue Island as a pilot project at the beginning of conservation in Kaimana by CI. Venue Island is one of the small islands located in the south of Buruway District which is only about 15 ha. The island has white sand beaches and beautiful coral reefs. As the name implies, it is the nesting nest of leatherback turtles and some endemic and migrant animal species. The island that holds that potential, is sanctioned by local indigenous people and suffers severe environmental damage. As Thamrin pointed out, Venue Island when it is going to conserve turtle captivity is rejected even to the confiscation of CI assets by local indigenous peoples. The rejection was a result of a mistake in approaching local indigenous peoples, resulting in a disparity in perceptions of conservation itself between CI and local indigenous peoples. Once the pattern of approaches has been changed, through intense communication with local indigenous peoples by prioritizing the 
socio-cultural aspects of informing the conservation conceptions carried out on Venue Island, the society turned to support and restore all assets seized.

This inequality of perception of conservation generally occurs in the view of the Working Group on Conservation Policy, due to differences in viewpoint between conservation managers (in this case: $\mathrm{CI}$ ) and the Society, especially those living around the area. Managers generally view that a unique, distinct and intact nature must be protected so that the surrounding population is a threat. Allocation, access, and control are defined by managers on the basis of modern science. While communities perceive that forests are the result of social construction between communities and surrounding ecosystems, local knowledge of communities is the basis for allocating, accessing and controlling these natural resources.

Understanding these differences of perspective is important for the sustainability of natural resource management because it is undeniable that the conservation areas in Kaimana cannot be separated from the characteristics of the Kaimana society by taking into account local rights and customary systems. Understanding how the public view is realized by CI by applying the appropriate environmental communication strategy in accordance with the characteristics of the Kaimana society, which still retains custom in their social life.

Efforts to communicate with the custom approach in order to gain commitment from indigenous peoples is through customs declaration event of "Sinara" installation. Sinara is a tradition of Kaimana indigenous people, a kind of sesajeun with sesajeun type according to tradition in every Kaimana region. Sinari basically understood the effort to invoke the prayer of salvation when initiating the activity, so that after the ceremony Sinara ceremony, followed by the reading of the prayers, according to their respective religious beliefs.Some research on the relationship between local wisdom and environmental preservation has been carried out by several experts [11]-[14].

Sinari ever implemented on $17^{\text {th }}$ of September 2015, together with the Office of Marine and Fisheries District, CI held a Customary Declaration Titanni System Zoo Arguni Gulf Group. The purpose of this customary declaration is to lay the groundwork for indigenous peoples' commitments, especially the 5 (five) villages in the Tugarni Group. Participants who attended the Titanni Group Zoning Custom Declaration were from 5 villages in the Tugarni Group as well as from neighboring villages such as the Sawi Group and invited stakeholders. Beginning with the process of installing the rhyme in places that have been determined by the chiefs of custom and petuanan of 5 villages belonging to the Tugarni Group, Arguni Bay event then followed by picking up invited guests using local customs such as pengalungan local bag (tomang) to the head Arguni Bay District, as representative of Kaimana regional government, also to the leadership of CI Kaimana, and Chairman of Kaimana Regency Customary Council.

According to Sinara is the nomenclature for custom rituals in the form of prayers and offerings for Tete Nene ancestors[15]. Sinara also refers to the known offer terminations on the coast of Kaimana-Fakfak. Sinara is intended for the spirits, the inhabitants of darkness. Arguni Society, Kaimana Regency, West Papua Province generally do a sinara to communicate with manggarega. This nomenclature refers to the spirit or supernatural beings of the rulers of darkness. Sinara is considered as an offering for the mangarega-mangarega, who is believed to control and watch the unseen nature of the waters and land of Arguni Bay. $\mathrm{He}$ is also believed to be awaiting the natural resources of the Arguni region.

Sinara's activity is basically a communication medium that $\mathrm{CI}$ is doing with local indigenous peoples in an effort to support conservation to be effective, involve society participation, and implement conservation that promotes sustainable environmental preservation. This is in line with the definition by $\mathrm{OECD}[15]$, that environmental communication as a plan and strategy using the process of communication and media products 
to support effective policymaking, public participation and project implementation that emphasizes sustainable environmental development [16], [17].

According to Shinta, environmental socialization activities conducted by CI are also conducted in the form of face-to-face, discussing directly with the society or school visits, especially if there are certain events, such as fishing crab activities. Shinta further said that conservation activities involve the society, such as a society watchdog group (Pokmaswas), which currently has 10 Pokmaswas posts scattered at several points in Kaimana, including turtle protection post that involves the society to the vigil. Other communication media used by CI include mass media, websites, online media, such as Instagram and youtube.

\section{Conclusions}

Based on the above explanation, obtained some conclusions related to environmental communication activities in Kaimana conservation area, among others:

Regional Marine Conservation Area or Kawasan Konservasi Laut Daerah (KKLD) Kaimana as an effort to maintain environmental quality and balance of the ecosystem. Utilization of resources owned for the life of Kaimana society while maintaining its sustainability and sustainability and paying attention to local Kaimana wisdom.

The role of CI through environmental communication activities is crucial in supporting sustainable environmental conservation in the Kaimana watershed area since environmental communication is essentially protecting the richness of natural resources with its diversity and promoting its sustainability by taking into account the socio-cultural conditions of local communities.

Environmental communication is carried out by CI Kaimana in an effort to foster social awareness and participation in conservation management through custom-based approach.

Environmental communication through customary approaches, such as Sinara and through mass media by providing release around conservation. Through online media such as website, Instagram or youtube as an effort to inform, educate and finally in turn to raise awareness and participation of all levels of the society.Direct face-to-face communication, direct discussion with the society and visits to schools conducted by CI with all its limitations, especially in implementing events related to conservation activities.

\section{References}

[1] Konservasi dan Keanekaragaman Hayati Laut, "Kawasan Konservasi Perairan Daerah (KKPD) Kaimana Regency," Konservasi dan Keanekaragaman Hayati Laut, 2014. [Online]. Available: http://kkji.kp3k.kkp.go.id/index.php/basisdata-kawasankonservasi/details/1/98.

[2] D. A. Bakar, "Good, the Bad and the Ugly: Framing the Country Development through Environmental Communication," Procedia - Soc. Behav. Sci., vol. 168, pp. 8 12, 2015.

[3] D. Yang, W. T. M. Kao, N. Huang, R. Wang, X. Zhang, and W. Zhou, "Process-based environmental communication and conflict mitigation during sudden pollution accidents," J. Clean. Prod., vol. 66, pp. 1-9, 2014.

[4] J. Nölle, M. Staib, R. Fusaroli, K. Tylén, and K. Tylén, "The emergence of systematicity: how environmental and communicative factors shape a novel communication system," Cognition, vol. 181, no. August, pp. 93-104, 2018. 
[5] A. M. Friedlander, "Marine conservation in Oceania: Past, present, and future," Mar. Pollut. Bull., vol. 135, no. March, pp. 139-149, 2018.

[6] I. V. Muralikrishna and V. Manickam, "Natural Resource Management and Biodiversity Conservation," in Environmental Management, Amsterdam: Elsevier, 2017, pp. 23-35.

[7] D. Asteria, E. Suyanti, D. Utari, and D. Wisnu, "Model of Environmental Communication with Gender Perspective in Resolving Environmental Conflict in Urban Area (Study on the Role of Women's Activist in Sustainable Environmental Conflict Management)," Procedia Environ. Sci., vol. 20, pp. 553-562, 2014.

[8] C. Jaca, V. Prieto-Sandoval, E. L. Psomas, and M. Ormazabal, "What should consumer organizations do to drive environmental sustainability?," J. Clean. Prod., vol. 181, pp. 201-208, 2018.

[9] A. Boggia, G. Massei, L. Paolotti, L. Rocchi, and F. Schiavi, "A model for measuring the environmental sustainability of events," J. Environ. Manage., vol. 206, pp. 836845, Jan. 2018.

[10] E. M. Angi, Kebijakan Pemerintah Pusat di Bidang Konservasi dari Perspketif Daerah dan Masyarakat. Bogor: CIFOR, 2005.

[11] S. Kakoty, "Ecology, sustainability and traditional wisdom," J. Clean. Prod., vol. 172, pp. 3215-3224, 2018.

[12] V. R. Vitasurya, "Local Wisdom for Sustainable Development of Rural Tourism, Case on Kalibiru and Lopati Village, Province of Daerah Istimewa Yogyakarta," Procedia Soc. Behav. Sci., vol. 216, no. October 2015, pp. 97-108, 2016.

[13] X. Fu, X. Wang, C. Schock, and T. Stuckert, "Ecological wisdom as benchmark in planning and design," Landsc. Urban Plan., vol. 155, pp. 79-90, Nov. 2016.

[14] A. Salisu Barau, L. C. Stringer, and A. U. Adamu, "Environmental ethics and future oriented transformation to sustainability in Sub-Saharan Africa," J. Clean. Prod., vol. 135, pp. 1539-1547, Nov. 2016.

[15] Mustaghfirin, "No Title," 2014.

[16] B. Birim, "Evaluation of Corporate Social Responsibility and Social Media as Key Source of Strategic Communication," Procedia - Soc. Behav. Sci., vol. 235, no. October, pp. 70-75, 2016.

[17] Y. Yang and G. Yu, "The analysis of social resource mobilization on new media: A case study of Chinese environmental protection documentary Under the Dome," Telemat. Informatics, vol. 37, no. April, pp. 128-136, Apr. 2019. 